\title{
Purification and characterization of fat body lipase from the greater wax moth, Galleria mellonella (Lepidoptera: Pyralidae)
}

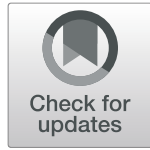

\author{
Rahma R. Z. Mahdy, Shaimaa A. Mo'men, Marah M. Abd El-Bar ${ }^{*}$ and Emad M. S. Barakat
}

\begin{abstract}
Background: Insect lipid mobilization and transport are currently under research, especially lipases and lipophorin because of their roles in the production of energy and lipid transport at a flying activity. The present study has been conducted to purify intracellular fat body lipase for the first time, from the last larval instar of Galleria mellonella.
\end{abstract}

Results: Purification methods by combination of ammonium sulfate $\left[\left(\mathrm{NH}_{4}\right)_{2} \mathrm{SO}_{4}\right]$ precipitation and gel filtration using Sephadex G-100 demonstrated that the amount of protein and the specific activity of fat body lipase were $0.008633 \pm$ $0.000551 \mathrm{mg} / \mathrm{ml}$ and $1.5754 \pm 0.1042 \mu \mathrm{mol} / \mathrm{min} / \mathrm{mg}$ protein, respectively, with a 98.9 fold purity and recovery of $50.81 \%$. Hence, the sephadex G-100 step was more effective in the purification process. SDS-PAGE and zymogram revealed that fat body lipase showed two monomers with molecular weights of 178.8 and $62.6 \mathrm{kDa}$. Furthermore, biochemical characterization of fat body lipase was carried out through testing its activities against several factors, such as different temperatures, $\mathrm{pH}$ ranges, metal ions, and inhibitors ending by determination of their kinetic parameters with the use of p-nitrophenyl butyrate (PNPB) as a substrate. The highest activities of enzyme were determined at the temperature ranges of $35-37^{\circ} \mathrm{C}$ and $37-40^{\circ} \mathrm{C}$ and $\mathrm{pH}$ ranges of $7-9$ and $7-10$. The partially purified enzyme showed significant stimulation by $\mathrm{Ca}^{2+}, \mathrm{K}^{+}$, and $\mathrm{Na}^{+}$metal ions indicating that fat body lipase is metalloproteinase. Lipase activity was strongly inhibited by some inhibitors; phenylmethylsulfonyl fluoride (PMSF), ethylene-diaminetetractic acid (EDTA), and ethylene glycoltetraacetic acid (EGTA) providing evidence of the presence of serine residue and activation of enzymes by metal ions. Kinetic parameters were $0.316 \mathrm{Umg}^{-1} V_{\max }$ and $301.95 \mathrm{mM} \mathrm{K}$.

Conclusion: Considering the purification of fat body lipase from larvae and the usage of some inhibitors especially ion chelating agents, it is suggested to develop a successful control of Galleria mellonella in near future by using lipase inhibitors.

Keywords: Galleria mellonella, Purification, Characterization, Intracellular lipase, Fat body lipase

\section{Background}

Lipases are the enzymes responsible for the hydrolysis of lipid (triacylglycerol acylhydrolase, EC 3.1.1.3) which catalyze the fatty acids ester bonds hydrolysis. These enzymes have significant functions in the usage, storage, and transmission of lipids in insects. They are also essential in fundamental physiological processes such as reproduction, development, protection against pathogens and oxidative stress, and pheromone signaling

\footnotetext{
* Correspondence: marah_elnaggar@sci.asu.edu.eg;

marah_elnaggar@yahoo.com

Department of Entomology, Faculty of Science, Ain Shams University, Abbassyia, Cairo 11566, Egypt
}

(Horne et al. 2009). Insect lipases are classified into triacylglycerol lipases (TAG-lipases), alkaline and acid phosphatases in addition to phospholipases (Terra and Ferreira, 2012).

Lipases have a dynamic physiological role; the catabolism of triacylglycerols (TAGs) that stored as depots of fat and those from nutritional lipids. Henceforth, two basic groups of lipase are documented, lysosomal (intracellular) and digestive lipases (Miled et al., 2000). Intracellular lipases, stored as lipid droplets are responsible for TAGs hydrolysis, the chief endogenous energy source (Wolins et al. 2006), while digestive lipases hydrolyze TAGs in food. 
The greater wax moth, Galleria mellonella (G. mellonella), is one of the most destructive pests of honey bee colonies worldwide (Oh et al. 1995). It causes considerable economic losses to beekeepers by damaging wax combs. The destruction of the comb is responsible for leaking or contaminating stored honey, killing bee larvae or causing the spreading of honey bee diseases (Caron, 1992). However, an actual method of controlling this pest has not been developed. Physical and chemical methods are unsatisfactory (Burges, 1978). Therefore, many studies have been directed to find solutions to controlling it. It is mandatory to study the enzymes of the insect pests for developing biotechnological methods to provide perfect and effective control measures (Oh et al., 1995).

Recently, insect lipid mobilization and transport are currently under search, especially lipases and lipophorin because of their roles in the production of energy and lipid transport at a flying activity. Most of the researches carried out on insect lipase focused on midgut lipase, while little researches have been carried out on fat bodies (Orscelk et al. 2007; Patel et al. 2005). Lipases have been purified from some insects, such as Manduca sexta (Arrese and Wells, 1994); Gryllus campestris (Orscelk et al., 2007); Locusta migratoria (Van der Horst et al. 2001); and Naranga aenescens (Zibaee, 2012).

Detailed knowledge of the enzymatic environment of Galleria will provide new chances for a maintainable pest management to control this pest. The wax moth is a highly specialized insect; its larva feeds on bees wax and probably has a unique system for lipid transport and usage (Wlodawer and Lạgwińska 1967).

According to the available literature, in wax moth, no intracellular lipase has been purified and characterized yet. Therefore, the current study aims to purify and characterize the fat body lipase of G. mellonella larvae.

\section{Materials and methods}

Rearing and maintenance of studied insect

The greater wax moth, G. mellonella (L.) was obtained from Plant Protection Research Institute, Agricultural Research Center, Egypt. A stock colony of G. mellonella was maintained for several generations in the insectary of Entomology Department, Faculty of Science, Ain Shams University and reared on artificial diet according to (Kulkarni et al. 2012). This colony was kept in constant darkness at $30 \pm 2{ }^{\circ} \mathrm{C}$ in a 5 -l screen gallon with the diet mixture containing pollen and bee wax. The larvae during the last stage were collected for further experiments.

Processing and preparation of larval tissue homogenates Collection of fat body tissues of G. mellonella larvae was prepared according to Fuchs et al. (2010). Larvae were cut from the upper part of the body distally to the lower part. The larval body was squeezed to discard the hemolymph, and the fat body was dissected out under ice cold distilled water.

Pooled tissues from 50 individuals (These insects convey $\sim 350 \mu$ g fat body tissue) were immediately transported to buffered saline ( $\mathrm{pH}: 6.9$ ) and weighed before analysis. Experimental fat body tissue was placed in a pre-cooled glass homogenizer and crushed in $1 \mathrm{ml}$ of buffer solution ( $\mathrm{pH} 7$ ). The homogenate was transferred to $2 \mathrm{ml}$ centrifuge tubes and centrifuged at $13,000 \mathrm{rpm}$ (Human Centrifuge, TGL-16XYJ-2, 16,000 rpm, Korea) for approx. $20 \mathrm{~min}$ at $4{ }^{\circ} \mathrm{C}$. The supernatant was stored at $-20^{\circ} \mathrm{C}$ for subsequent analyses.

\section{Estimation of protein concentration}

The method of Bradford (1976) was applied to measure the protein concentration by using bovine serum albumin (BSA) as a standard protein.

\section{Determination of lipase activity}

Lipase activity was determined by using the continuous spectrophotometric rate determination method as documented by Tsujita et al. (1989) with some modifications. The enzyme activity for samples at the beginning of the purification procedure was assayed using the following substrate solution: unlabeled trioleoylglycerol (final concentration $2 \mathrm{mM}$ ) and Triton X-100 (final concentration $10 \mathrm{mM})$ were dissolved in toluene-ethanol 1:l (v/v), and purified; radiolabeled trioleoylglycerol was added to give a specific activity of about $7 \times \mathrm{lo}^{\text {**: }} \mathrm{dpm} / \mathrm{mol}$. Paranitrophenyl butyrate (PNPB) (final concentration 27 and 50 $\mathrm{mM}$ ). Thirty microliters of crude extracts (from fat body) and $100 \mu \mathrm{l}$ of p-nitrophenyl butyrate (PNPB, 50 $\mathrm{mM})$, as substrate were thoroughly mixed and incubated at $37^{\circ} \mathrm{C}$. For samples of negative control, the tubes were put in a boiling water bath for 20 min to destroy the activity of enzyme then cooled. Saline buffer $(100 \mu \mathrm{l})$ were supplemented to each tube (control and treatment), and the absorbance was read at $405 \mathrm{~nm}$ with a spectrophotometer (UNICO, SP2100 UV, China) for approximately $5 \mathrm{~min}$, then the absorbency/min (total activity) was obtained by means of the maximum linear rate for both the test and blank.

Specific enzyme activity as unit $/ \mathrm{min} / \mathrm{ml}$ protein was calculated according to the following equation:

Units $/ \mathrm{mg}$ protein $=$ units $/ \mathrm{ml}$ enzyme $/ \mathrm{mg}$ protein $/ \mathrm{ml}$ enzyme.

\section{Purification of fat body lipase}

Purification of the tissue lipase extracted from the fat body was achieved in the two steps established on a 
process described by Orscelk et al. (2007), with some adjustments.

\section{Ammonium sulfate $\left[\left(\mathrm{NH}_{4}\right)_{2} \mathrm{SO}_{4}\right]$ precipitation}

Samples were first exposed to $\left[\left(\mathrm{NH}_{4}\right)_{2} \mathrm{SO}_{4}\right]$ precipitation by making use of 40 and $80 \%$ of $\left[\left(\mathrm{NH}_{4}\right)_{2} \mathrm{SO}_{4}\right]$ solution and the $\left[\left(\mathrm{NH}_{4}\right)_{2} \mathrm{SO}_{4}\right]$ fraction was then gathered and centrifuged at $10,000 \mathrm{rpm}$ for $20 \mathrm{~min}$. All the precipitation steps were performed at $4{ }^{\circ} \mathrm{C}$, and in each step, the activity of enzyme and content of protein were determined (Additional file 1).

\section{Sephadex G-100 gel filtration chromatography}

The final fraction of $\left[\left(\mathrm{NH}_{4}\right)_{2} \mathrm{SO}_{4}\right]$ was exposed to gel filtration on a Dried Sephadex G-100 column. The dried gel was incubated in distilled water for $5 \mathrm{~h}$ at $90^{\circ} \mathrm{C}$. It was loaded onto the column $(12 \times 2 \mathrm{~cm})$ at $27^{\circ} \mathrm{C}$, after its cooling and removal of air. Afterward, $20 \mathrm{mM}$ universal buffer ( $\mathrm{pH} 10)$ was used for equilibration of the column, containing $50 \mathrm{mM}\left[\left(\mathrm{NH}_{4}\right)_{2} \mathrm{SO}_{4}\right]$. Three milliliters enzyme fractions were collected at a flow rate of $20 \mathrm{ml} / \mathrm{h}$ with the same buffer. Content of protein and activity of lipase were measured and fractions that showed the highest activities were pooled for the last step. Sephadex G-100 was obtained from Pharmacia Fine Chemicals, and experiment applied at Regional Center for Mycology and Biotechnology, Al-Azhar University, Cairo, Egypt.

Purification fold and yield\% was calculated according to the following equations:

$$
\begin{aligned}
\text { Purification fold }= & \text { specific activity of purified enzyme } / \\
& \text { specific activity of unpurified enzyme. }
\end{aligned}
$$

Yield $\%=($ Total activity of purified enzyme $/$ total activity of unpurified enzyme) $* 100$.

\section{Determination of molecular weight and purity of the purified lipase (electrophoretic analysis)}

The purity and molecular weight of the purified enzyme were determined by using sodium dodecyl sulfate polyacrylamide gel electrophoresis (SDS-PAGE), as explained by Laemmli (1970). A 4\% stacking gel and 15\% resolving gel were used.

The enzyme molecular mass was estimated using BL Uelf Prestained Protein Ladder (from Genedirex) as molecular mass standards (marker proteins).

A gel documentation system using a scanner was used to scan the gel, and then, analysis of bands was carried out using software: Gel-Pro Analyzer ver. 6.0.

\section{Zymogram analysis}

Lipase zymogram analysis was carried out according to methods of Prim et al. (2003), using MUF-butyrate (from Sigma) as the substrate. SDS-PAGE was performed using 15\% resolving and 4\% stacking gel. By ending of the run, the gel separated gently from glasses and rinsed immediately with distilled water then incubated in Triton X-100 $(2.5 \% \mathrm{v} / \mathrm{v})$ at room temperature, allowing the enzyme renaturation. Gels were rinsed again after $30 \mathrm{~min}$, with distilled water, and incubated in $100 \mathrm{ml}$ MUF-butyrate solution $(100 \mu \mathrm{M}$ in $50 \mathrm{mM}$ phosphate buffer at $\mathrm{pH} 8.0)$. After $10 \mathrm{~min}$, the gel was transferred to UV trans-illuminator to detect fluorescent bands in dark background.

\section{Determination of biochemical characteristics of the purified lipases \\ Effect of $\mathrm{pH}$ on lipase activity}

The $\mathrm{pH}$ effect on the activity of purified lipase was measured using lipase diluted in $15 \mu \mathrm{l}$ universal buffer (Stauffer, 1989). Buffers were made for the $\mathrm{pH}$ range from 2 to 13. Lipase activity was assayed as described above, after incubation for $1 \mathrm{~h}$ at each $\mathrm{pH}$ value.

\section{Effect of temperature on lipase activity}

Lipase was diluted in $15 \mu \mathrm{l}$ buffer $(50 \mathrm{mM}$ Tris- $\mathrm{HCl}$ at $\mathrm{pH} 7-7.5)$ then incubated at temperatures ranging from 20 to $70^{\circ} \mathrm{C}$ for $1 \mathrm{~h}$. Instantly post-incubation, the activity of lipase was determined using PNPB as the substrate, as described previously.

\section{Effect of mono- and di-valent cations on lipase activity}

The various ions $\left(\mathrm{CaCl}_{2}, \mathrm{NaCl}\right.$, and $\left.\mathrm{KCl}\right)$ effects on lipase activity were determined. Fifty microliters of buffer solution containing one concentration of ions $(0,10,20,30$, and $40 \mathrm{mM}$ ) along with $30 \mu \mathrm{l}$ of enzyme were preincubated for $1 \mathrm{~h}$ at $\mathrm{pH} 7.5$ and $37^{\circ} \mathrm{C}$. The mixture that pre-incubated was supplemented to a solution including $100 \mu \mathrm{l}$ of universal buffer (pH 7.5). Other steps were conducted out as mentioned before.

\section{Effect of specific inhibitors on lipase activity}

The enzyme inhibitors effects on activity of lipase were reported using different concentrations $(0,0.5,1,1.5$, and $2 \mathrm{mM}$ ) of ethylene glycol-bis ( $\beta$-aminoethylether) $\mathrm{N}$, $\mathrm{N}, \mathrm{N}^{\prime}, \mathrm{N}^{\prime}$-tetraacetic acid (EGTA), phenylmethylsulfonyl fluoride (PMSF), and Ethylenediamine tetraacetic acid (EDTA). The purified enzyme $(30 \mu \mathrm{l})$ was incubated with equal volumes of each inhibitor for $10 \mathrm{~min}$ at $\mathrm{pH} 7.5$ and $37^{\circ} \mathrm{C}$. The mixture was supplemented to a solution including $30 \mu \mathrm{l}$ of substrate (PNPB, $50 \mathrm{mM}$ ), and then the activity was measured as mentioned above.

\section{Kinetic parameters measurements}

The kinetic parameters (The Michaelis constant, $\mathrm{Km}$ and the maximum velocity $V_{\max }$ ) were determined according to (Walsh et al. 2010). Final concentrations for $p$-nitrophenol butyrate were 10, 20, 30, 40, and $60 \mathrm{mM}$, 
using $30 \mathrm{ul}$ of diluted enzyme preparations at $37^{\circ} \mathrm{C}$ and $\mathrm{pH} 7.5$ in each assay.

\section{Statistical analysis}

Data were expressed as mean \pm standard error (SE) of 3 replicates for each determination and analyzed by using the Minitab 18 statistical software. The difference between means was analyzed by student $t$ test after normality test and compared by the one-way analysis of variance (ANOVA) followed by Tukey's Test when $P \leq$ 0.05 . The $K_{m}$ and $V_{\max }$ of the enzyme were estimated by Microsoft Excel ${ }^{\circ}$.

\section{Results}

Purification of intracellular fat body lipase from $G$. mellonella larvae

The amount of protein content in crude extract from fat body tissue of G. mellonella larvae was $1.6702 \pm 0.023$ $\mathrm{mg} / \mathrm{ml}$, and specific lipase activity was $0.016102 \pm$ $0.000278(\mu / \mathrm{mg})$ (Additional file 1).

After the second phase of $\left[\left(\mathrm{NH}_{4}\right)_{2} \mathrm{SO}_{4}\right]$ precipitation, fat body lipase exhibited a specific activity of $0.0844 \pm$ $0.00216 \mathrm{U} / \mathrm{mg}$ protein, $1.68 \pm 0.0724 \mathrm{mg} / \mathrm{ml}$ of protein, $52.43 \%$ of recovery, and 5.3 fold purification (Table 1). The $\left[\left(\mathrm{NH}_{4}\right)_{2} \mathrm{SO}_{4}\right]$ fractions were then loaded to the Sephadex G-100 column. The sample was fractionated into 50 fractions from which 21 fractions showed lipase activity with three peaks of specific activities at fractions numbers 6,8 , and 17, and fraction number 6 showed the highest specific activity (Fig. 1). After the last purification step; protein and the specific activity amounts of fat body lipase were $0.008633 \pm 0.000551 \mathrm{mg} / \mathrm{ml}$ and $1.5754 \pm 0.1042 \mu \mathrm{mol} / \mathrm{min} / \mathrm{mg}$ protein, respectively with $50.81 \%$ recovery and 98.9 fold purification. Statistically, there was no significant difference in specific lipase activity between crude sample and sample after ammonium sulfate $\left[\left(\mathrm{NH}_{4}\right)_{2} \mathrm{SO}_{4}\right]$ precipitation steps but a large significant difference was observed between the latter samples and sample that undergo final step of purification (Fig. 2). That means the sephadex G-100 step was more effective in the purification process.
Determination of molecular weight and purity of the purified lipases from $G$. mellonella larvae: SDS-PAGE and zymogram

SDS-PAGE showed that several protein bands were eliminated after each purification step, and the lowest number of bands that appeared on the gel was after the final step (Fig. 3). Zymogram analysis yielded two bands with molecular weights of $178.8 \mathrm{kDa}$ and $62.6 \mathrm{kDa}$ for fat body (Fig. 4).

\section{Biochemical characterization of purified intracellular fat body lipase \\ The effect of $\mathrm{pH}$ on lipase activity}

The $\mathrm{pH}$ effect on lipase activity is shown in (Fig. 5) with significant differences $(p<0.05) . F$ values were 379.23 . The activity of the enzyme gradually increased from 4 to 8 and then reduced until $\mathrm{pH} 13$. Activity was high when assayed at $\mathrm{pH} 7-10$, with the maximal activity at $\mathrm{pH} 8$. Lipase activity was decreased at $\mathrm{pH} 3$.

\section{The effect of temperature on lipase activity}

The temperature effect on the activity of purified lipase was assessed throughout a range from 20 to $70{ }^{\circ} \mathrm{C}$ (Fig. 6). The purified lipase represented a gradual increase in its activity by incubation temperature elevation from 20 to $40^{\circ} \mathrm{C}$ and decreased until $70^{\circ} \mathrm{C}$. The Highest activity under these conditions was at both 37 and $40^{\circ} \mathrm{C}$. The statistical analysis demonstrated that the highest activity of the enzyme at 37 and $40{ }^{\circ} \mathrm{C}$ were similar to each other $(p \leq 0.05)(F=60.81)$.

\section{Effect of mono- and di-valent cations on fat body lipase activity}

Mono- and di-valent cations (in several concentrations) effects the purified lipase activity are shown in (Fig. 7). All different concentrations of $\mathrm{Ca}^{2+}$ significantly $(p \leq$ 0.05 ) increased the activity of fat body lipase as it was $2.918 \pm 0.0746 \mu \mathrm{mol} / \mathrm{min} / \mathrm{mg}$ protein in the highest concentration that is 2.144-fold more than of the activity of enzyme without using $\mathrm{Ca}^{2+}$. Effect of $\mathrm{Na}^{+}$and $\mathrm{K}^{+}$ showed a significant increase $(p<0.05)$ from 0 concentration of $\mathrm{Na}^{+}$and $\mathrm{K}^{+}$to $40 \mathrm{mM}$ concentration. $F$ values

Table 1 Purification process of fat body lipase from G. mellonella larvae

\begin{tabular}{llllll}
\hline Purification step & Protein $^{\mathrm{a}}(\mathrm{mg} / \mathrm{ml})$ & Total activity $^{\mathrm{b}}(\mathrm{U})$ & Specific activity $^{\mathrm{b}}(\mathrm{U} / \mathrm{mg})$ & Purification fold & $(\%)$ \\
\hline Crude extract & $1.68 \pm 0.0724$ (A) & $0.026767 \pm 0.000681(\mathrm{~A})$ & $0.015933 \pm 0.000288$ (B) & 1 & 100 \\
$\left(\mathrm{NH}_{4}\right)_{2} \mathrm{SO}_{4}(\mathrm{O}-40 \%)$ & $0.903 \pm 0.00608$ (B) & $0.024 \pm 0.0$ (B) & $0.0266 \pm 0.000177$ (B) & 1.67 & 89.7 \\
$\left(\mathrm{NH}_{4}\right)_{2} \mathrm{SO}_{4}(40-80 \%)$ & $0.16633 \pm 0.00551$ (C) & $0.014033 \pm 0.000153$ (C) & $0.0844 \pm 0.00216$ (B) & 5.3 & 52.43 \\
Sephadex G-100 & $0.008633 \pm 0.000551$ (D) & $0.0136 \pm 0.0001$ (C) & $1.5754 \pm 0.1042$ (A) & 98.9 & 50.81 \\
\hline
\end{tabular}

aprotein content was measured by the Bradford method (1976)

${ }^{b}$ One unit of activity corresponds to $1 \mu \mathrm{mol}$ of pNP released per min using $50 \mathrm{mM}$ pNPB as the substrate at $37^{\circ} \mathrm{C}$

Data are showed as (mean $\pm \mathrm{SE}$ ), $n=3$ replicates

Different letters indicate significant differences $(p<0.05)$ 


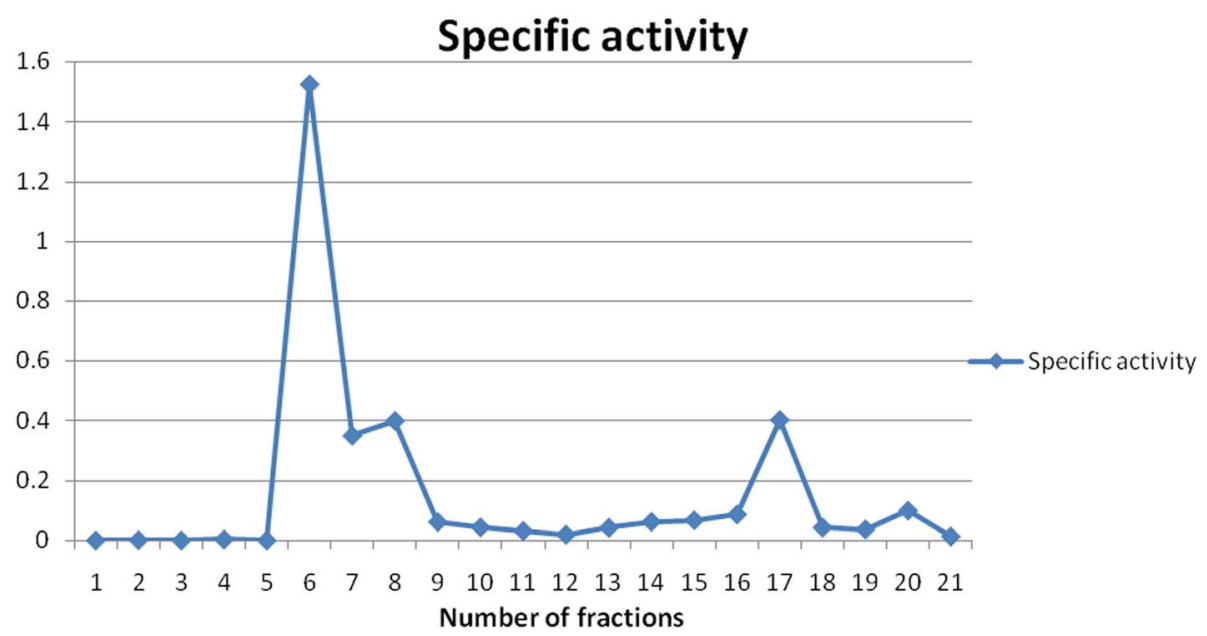

Fig. 1 Purification process of fat body lipase from $\mathrm{G}$. mellonella larvae. Sephadex $\mathrm{G}-100$ gel-filtration of lipase after ammonium sulfate [( $\left.\left.\mathbf{N H}_{4}\right)_{2} \mathbf{S O}_{4}\right]$ (40 and $80 \%$ ) treatment. Fractions number 6 to 21 contained the high enzymatic activity on PNPB $(50 \mathrm{mM})$ and fraction number 6 with the highest specific activity $(\mathrm{U} / \mathrm{mg})$ was collected for next steps, (no. of replicates $=3$ )

of fat body lipase tests were 104.95, 47.90, and 83.25 for $\mathrm{Ca}^{2}, \mathrm{Na}^{+}$, and, $\mathrm{K}^{+}$, respectively.

\section{Effect of specific inhibitors on lipase activity of G. mellonella}

We used PMSF (serine protease inhibitor), EGTA (calcium specific chelating agents), and EDTA (general chelating agent) to find the role of metal ions and serine residue in the active site of fat body lipase (Fig. 8). At different concentrations of PMSF, we recorded a significant inhibitory effect on fat body lipase with a sharp decrease in activity at $0.5 \mathrm{mM}$ concentration of inhibitor in comparison with control. For EGTA, the enzyme activity decreased at all the tested concentrations. Also EDTA had a significant gradual inhibitory effect on fat body lipase with the lowest activity at a concentration of $2 \mathrm{mM}$. The purified lipase activity gradually reduced by increasing concentrations of PMSF, EGTA, and EDTA pointing to the presence of metal ions especially $\mathrm{Ca}^{2+}$ and a serine residue in the active sites of the enzymes. Statistically, all tests were significantly different with $p$ value $<$ 0.05 .

Kinetic parameters of purified lipase from larval fat body of G. mellonella

The maximum velocity $\left(V_{\max }\right)$ and Michaelis constant $\left(K_{\mathrm{m}}\right)$ were calculated using several concentrations of $\mathrm{p}$ nitrophenol butyrate to measure kinetic parameters of

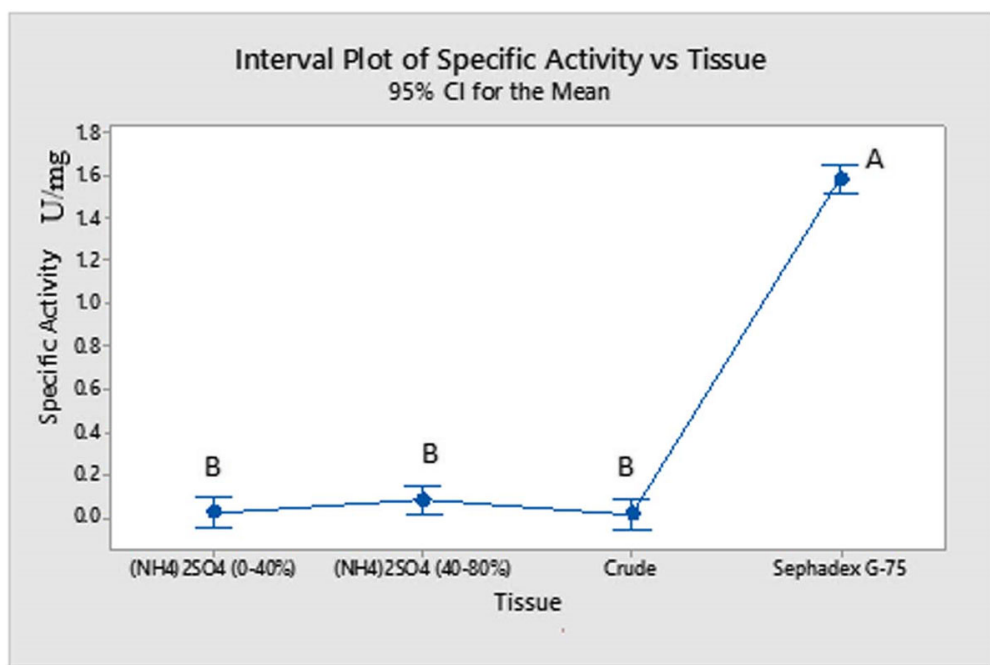

Fig. 2 Specific activity of fat body lipase before purification and during steps of purification. Different letters indicate significant differences $(p<0.05)$. (no. of replicates $=3$ ) 


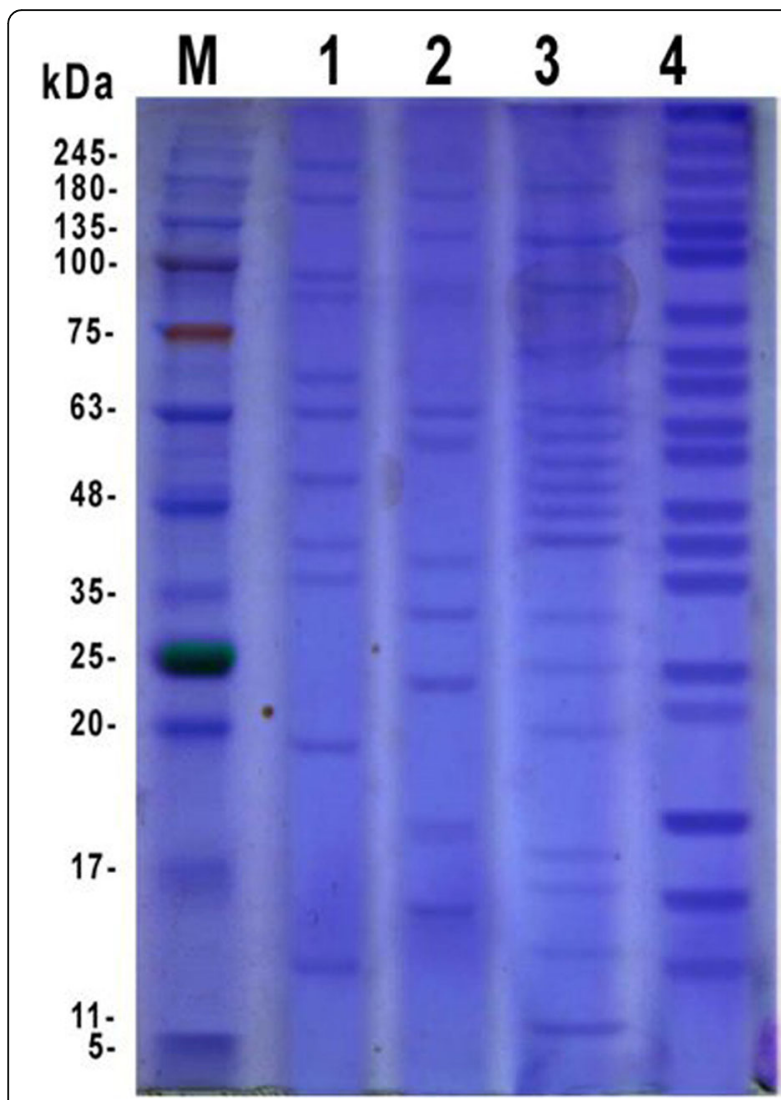

Fig. 3 SDS-PAGE of purified fat body lipase from G. mellonella larvae. M: molecular marker, 1: Fraction 17 after sephadex G-100 column, 2: Fraction 6 after loading column, 3: Sample after amm. Sulfate percipitation (40-80\%), 4: Unpurified fat body extract

the purified lipase. We found that; the $V_{\max }$ of fat body lipase was $0.316 \pm 1.24 \mathrm{U} / \mathrm{mg}$ protein while $K_{\mathrm{m}}$ was $301.59 \pm 24.973 \mathrm{mM}$ (Fig. 9). The statistical analysis showed $p$ value of 0.02 (Additional file 1).

\section{Discussion}

The presented study describes for the first time the possibility to use G. mellonella larvae for the identification of intracellular lipase extracted from the fat body. This study also provides direct tests for the characterization of enzyme properties by purification performance and biochemical approaches, which is an advantage for studies related to physiology and pest control.

The extracted lipase from larval and fat body was purified by using two steps. Non-protein components were separated from proteins using ammonium sulfate $\left[\left(\mathrm{NH}_{4}\right)_{2} \mathrm{SO}_{4}\right]$ in a salting-out process. Adding $\left[\left(\mathrm{NH}_{4}\right)_{2} \mathrm{SO}_{4}\right]$ decreased solvent molecules that interact with proteins by interacting with them (Robinson, 2015). Some proteins coagulate as precipitate because of decreasing the number of solvent molecules. Also, the separation of a specific enzyme from other proteins can be done through this step.

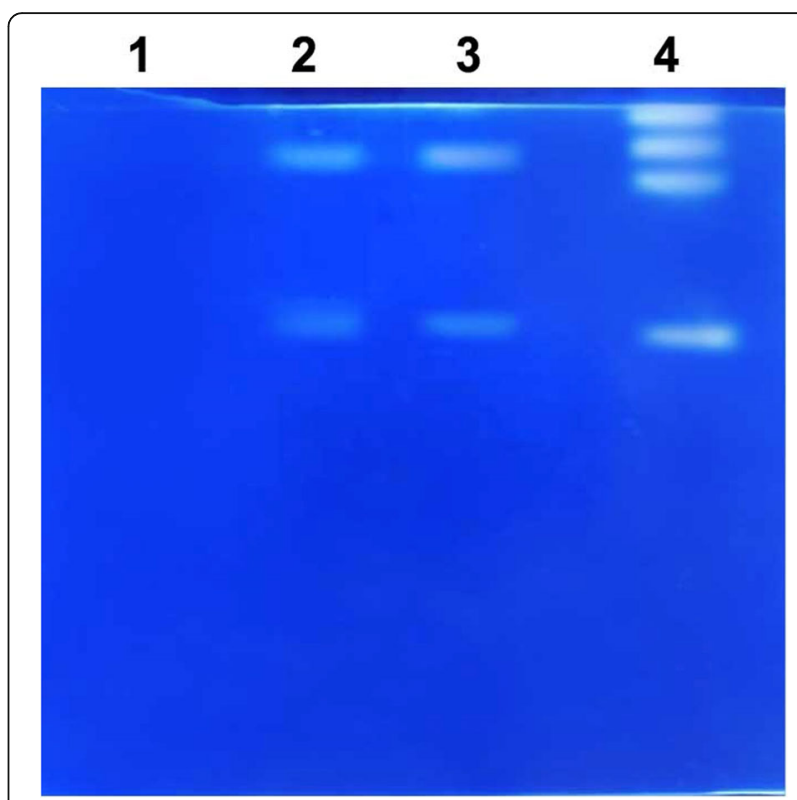

Fig. 4 Zymogram of purified fat body lipase from G. mellonella larvae. 1: Fraction 17 after sephadex G-100 column, 2: Fraction 6 after loading column, 3: Sample after amm. Sulfate percipitation (4080\%), 4: Unpurified fat body extract

A gel filtration followed the previous step which separates large proteins according to molecular weights. Very large proteins were excluded while the smaller ones entered between gel particles. Larger protein molecules passed down the column and recovered with shorter elution time (Robinson, 2015). It was found that the selected procedures for purification of the larval fat body lipase are operative to abolish some of contaminating proteins and non-protein molecules so that the final preparation showed to be electrophoretically more partially pure than crude by presentation few number bands on SDS-PAGE.

Various purification methods depend on non-specific techniques, precipitation, filtration of gel, ion exchange, affinity, and hydrophobic interaction chromatography have been used to isolate and purify different lipases. Orscelk et al. (2007) have purified the total body lipase from Gryllus campestris by ammonium sulfate $\left[\left(\mathrm{NH}_{4}\right)_{2} \mathrm{SO}_{4}\right]$ precipitation followed by gel filtration. Ranjbar et al. (2015) has purified digestive lipases purified from several insects by three purification steps, such as Ectomyelois ceratoniae (Ranjbar et al., 2015); Naranga aenescens by Zibaee (2012) and from Antheraea drury by Marepally and Benarjee (2016).

In the current study, protein profiles were resolved by (SDS-PAGE). Electrophoretic separation was achieved at a $15 \mathrm{~mA}$ constant current and at $2{ }^{\circ} \mathrm{C}$. Coomassie brilliant blue R-250 was used to visualize the separated proteins. In our study, the analyzed fractions show fewer numbers of bands than crude by SDS-PAGE that is due 


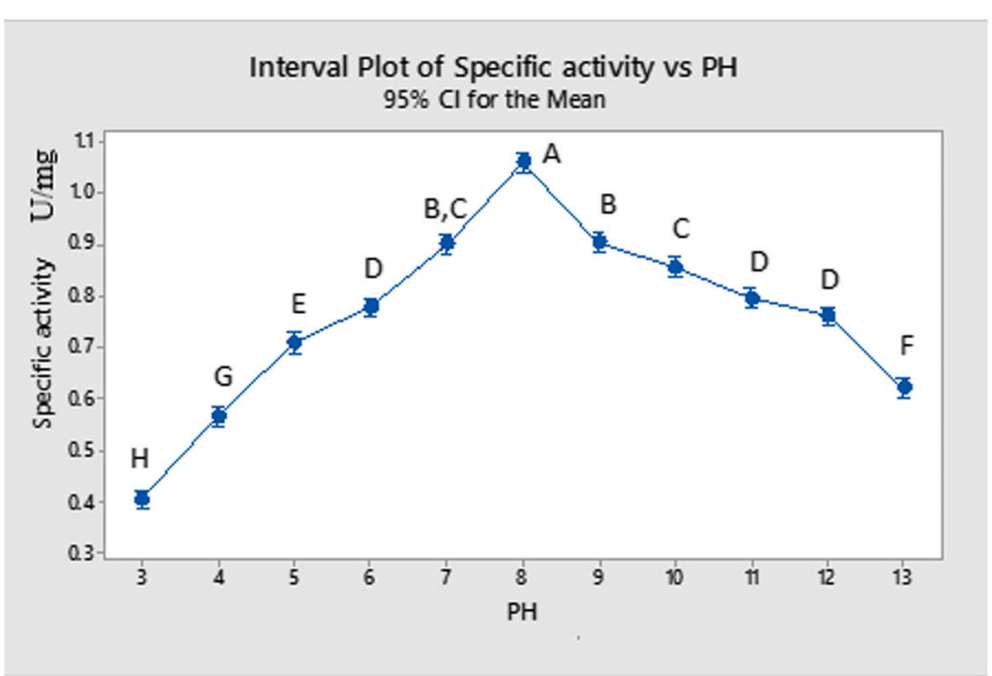

Fig. 5 Effect of pH on activity of purified fat body lipase from larvae of G. mellonella by using different pH range. Different letters indicate significant differences $(p<0.05)$, (no. of replicates $=3$ )

to the elimination of unwanted proteins from fractions through purification processing. Invertebrate lipases vary widely in their molecular mass. Zymographic analysis showed that intracellular fat body lipase consisted of two monomers with molecular mass of $178.8 \mathrm{kDa}$ and 62.2 $\mathrm{kDa}$. Indeed, nature of enzyme varies with food and organism from which they extracted (Agusti and Cohen, 2000; Hubert et al. 1999; Torres and Bayd, 2009; Zeng and Cohen 2000a, 2000b). Other molecular masses were observed for many insects such as $76 \mathrm{kDa}$ for fat body lipase of M. sexta (Arrese and Wells, 1994), $30 \mathrm{kDa}$ for lipase of Cephaloleia presignis (Auerswald and Gäde, 2006), $28 \mathrm{kDa}$ for lipase from digestive juices of Bombyx mori (Ponnuvel et al., 2003) and $196 \mathrm{kDa}$ for intracellular lipase from Litopenaeus vannamei pleopods (RiveraPérez and García-Carreño, 2011).

The $\mathrm{pH}$ is one of the most vital factors which biochemical reactions depend on. Fat body lipase showed the greatest activity at $\mathrm{pH} 8$ followed by 9 while most activity was lost at $\mathrm{pH} 3$. It seems that lipases from G. mellonella have a slightly alkaline optimum $\mathrm{pH}$, these results are in conscience with that of kissing bug, $R$. prolixus which have high lipase activity at $\mathrm{pH} 7.0-7.5$ (Grillo et al. 2007), and tobacco hornworm M. sexta at pH 7.9 (Arrese and Wells, 1994).

The high activity of the enzyme at certain $\mathrm{pH}$ indicates where the organism feeds in an environment (Grillo et al., 2007). The $\mathrm{pH}$ affects the enzyme activity by

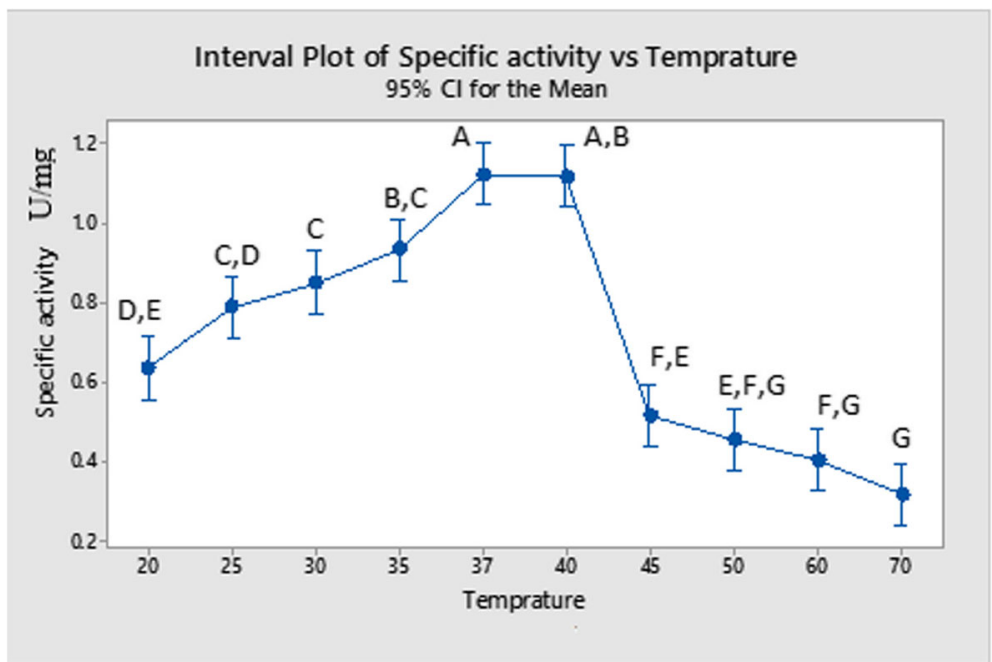

Fig. 6 Effect of temperature $\left({ }^{\circ} \mathrm{C}\right)$ on activity of purified fat body lipase from larvae of $\mathrm{G}$. mellonella by using different temperature range. Different letters indicate significant differences $(p<0.05)$, (no. of replicates $=3$ ) 


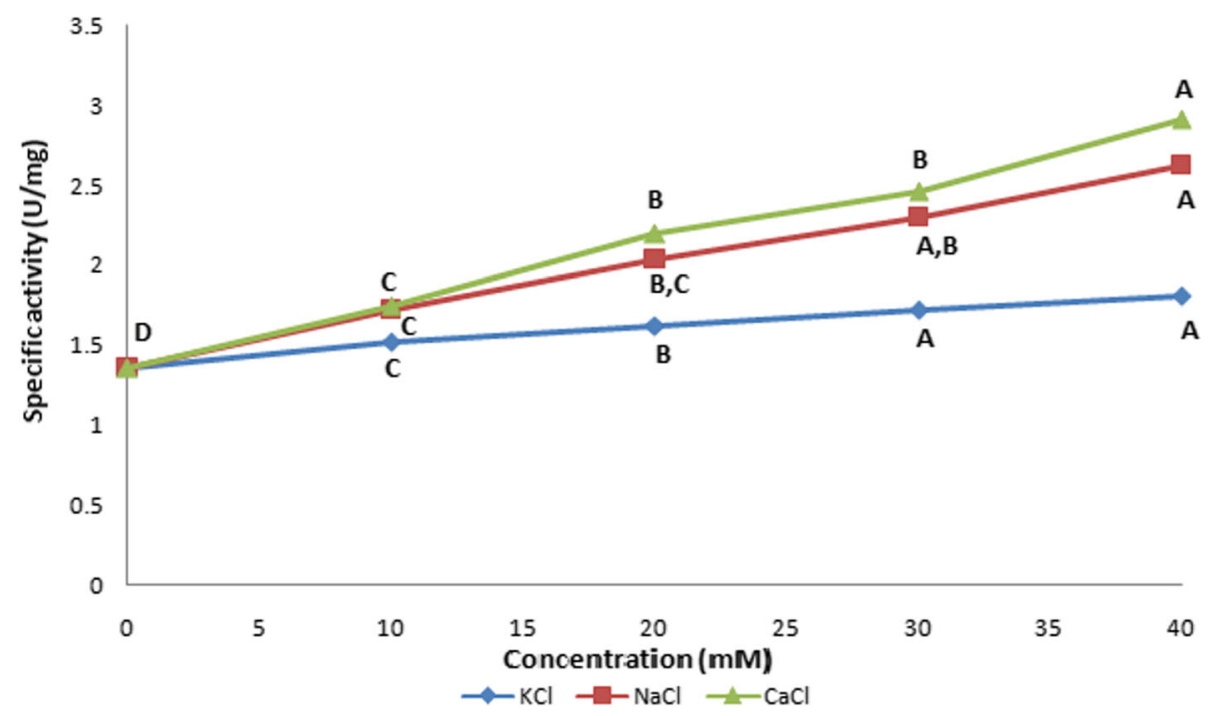

Fig. 7 Effect of $\mathrm{KCl}, \mathrm{NaCl}$ and $\mathrm{CaCl}_{2}$ on purified lipase from larval fat body tissue of $\mathrm{G}$. mellonella. All experiments were carried out at $37^{\circ} \mathrm{C}$. PNPB $(50 \mathrm{mM})$ was used as substrate. The enzyme reaction was incubated with ions separately for $1 \mathrm{~h}$. Different letters indicate significant differences $(p<0.05)$, (no. of replicates $=3$ )

charge altering of substrate or enzyme active site. Very high and low $\mathrm{pH}$ can cause electrostatic repulsion (Roussel et al. 1999). The $\mathrm{pH}$ extremes can also interrupt the hydrogen bonds that keep the enzyme in its three-dimensional structure (Zeng and Cohen, 2000a). However, these changes may be canceled if the enzyme returned to its optimal conditions (Robinson 2015).

Another factor that biochemical reactions rely on is temperature. In the current study, the temperature effect on lipase activity was assessed over a range from 20 to $70^{\circ} \mathrm{C}$. The maximum activity for fat body intracellular lipase was at $37-40^{\circ} \mathrm{C}$ while the minimum activity was at $70^{\circ} \mathrm{C}$. It was concluded that the enzyme activity reached its peak at the most suitable range of temperature then this activity decreased by increasing the temperature above the suitable one till reached the point at which enzyme denatured then activity decreased sharply. High temperature may interfere with the hydrogen bond of enzyme causing denaturation of this enzyme (Zeng and Cohen, 2000a). Parallel results have been revealed in other insect lipases, as in gypsy moth Lymantria dispar (Mrdaković et al. 2008), Rhynchophorus palmarum (Santana et al. 2017) and $N$.

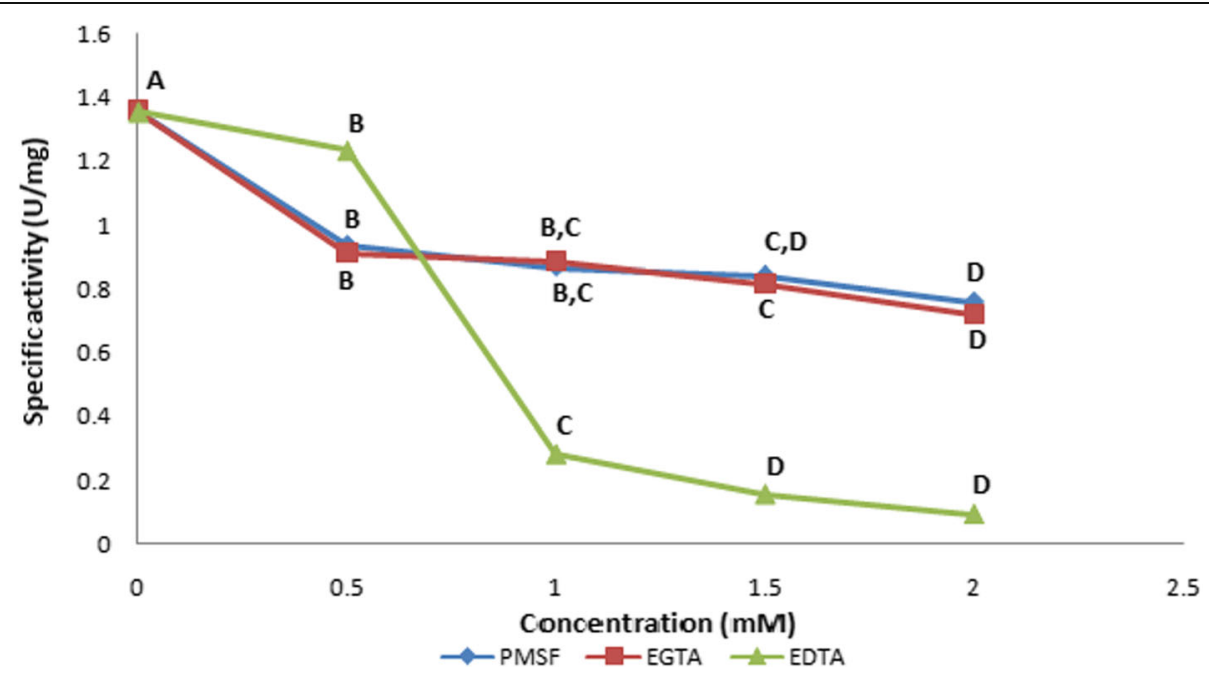

Fig. 8 Effect of PMSF, EGTA and EDTA on purified lipase from larval fat body tissue of G. mellonella. All experiments were carried out at $37^{\circ} \mathrm{C}$. PNPB $(50 \mathrm{mM})$ was used as substrate. The enzyme reaction was incubated with various concentrations of inhibitor separately for 10 min. Different letters indicate significant differences $(p<0.05)$, (no. of replicates $=3$ ) 


\section{Lineweaver-Burk Plot $y=954.4 x+3.160$

$$
R^{2}=0.989
$$

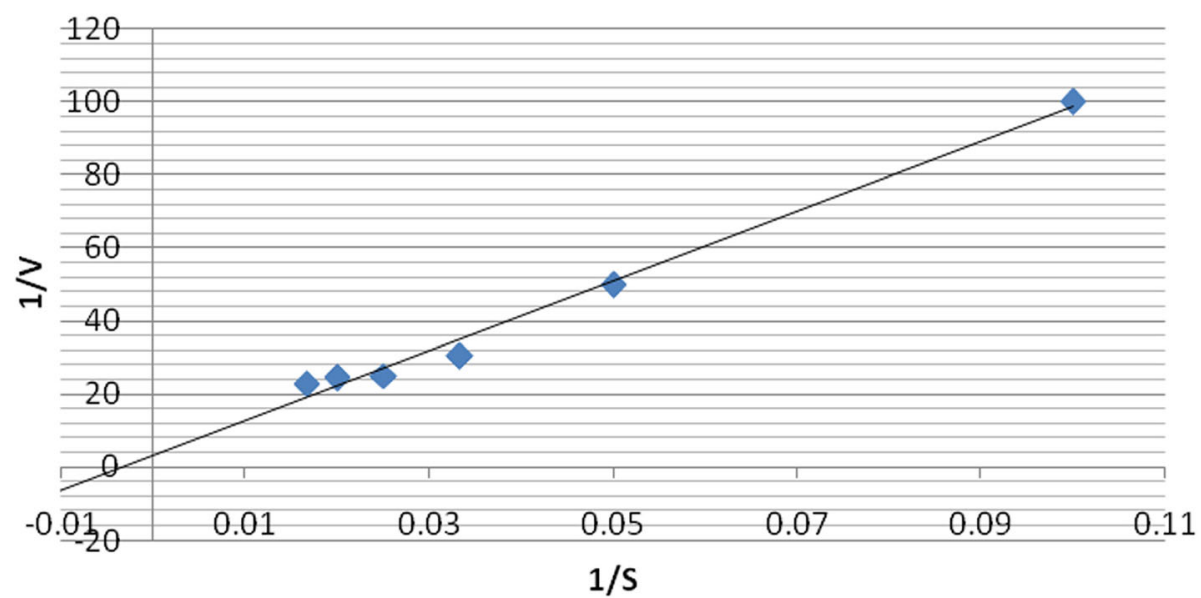

Fig. 9 Double reciprocal plot to show the kinetic parameters of purified lipase from the larval fat body tissue of G. mellonella by using PNPB (from 10 to $60 \mathrm{mM})\left(1 \mathrm{~N}_{\max }=\right.$ intercept on the $1 \mathrm{~N}_{0}$ ordinate, $\mathrm{Km} / \mathrm{Vmax}=$ the slope of the regression line

aenescens (Zibaee, 2012). In contrast, some invertebrates showed the highest activity of lipase at $60^{\circ} \mathrm{C}$ such as the Mediterranean green crab Carcinus mediterraneus (Cherif et al., 2007) and the Antarctic krill Euphasia superba (Barriga González, 2006).

In our investigation, it was found that $\mathrm{CaCl}_{2}, \mathrm{NaCl}$, and $\mathrm{KCl}$ had an increasing effect on the partially purified lipase activity from the fat body of G. mellonella larvae. All different concentrations of $\mathrm{Ca}^{2+}, \mathrm{Na}^{+}$, and $\mathrm{K}^{+}$significantly increased the activity of fat body intracellular lipase.

Similar results were shown for other insects; Grillo et al. (2007) and Santana et al. (2017) show that the activity of lipase from $R$. prolixus and Rhynchophorus palmarum increases by increasing calcium ion concentrations respectively. Researches on C. suppressalis by Zibaee et al. (2008) and on $N$. aenescens by Zibaee (2012) reveal the same conclusion. All previous results indicate that the purified lipase is metalloproteinase, an enzyme whose catalytic mechanism involves metal ions, and this result is confirmed by using EDTA and EGTA in the current study.

On the other hand, Rivera-Pérez and García-Carreño (2011) conclude that invertebrate lipases are not influenced by calcium moderate concentration for maximum activity and stability, as noticed in mammalian lipases, for example, adipose tissue lipase show its maximum activity at $10 \mathrm{mM} \mathrm{CaCl}_{2}$. The same conclusion is stated by Mrdaković et al. (2008), on the digestive lipase from gypsy moth, $L$. dispar that is not governed by $\mathrm{Ca}^{+2}$ for activation or stability. These authors depending on the observation of Kim et al. (1997) about lipase from Pseudomonas cepacia which state that the stabilization of lipase triad structure is due to the structure of calcium-binding site which consists of two carboxylate groups of Asp242 and Asp288 and two carbonyl groups of Gln292 and Val296, taking in consideration that not all invertebrates have this site.

There are several ways by which ions can affect enzyme activity; one of these ways is keeping the enzyme and substrate near to each other to enhance enzyme activity. Also, they preclude the unwanted reaction of nucleophiles and put the active groups of enzyme and substrate in the most perfect location leading to an increase in the ability of enzyme-substrate complex and enzyme stability (Santana et al., 2017).

Inhibitors are chemicals that diminish enzyme activity. They affect the catalytic characteristics of active site directly or indirectly (Robinson, 2015). In this study, three chelating agents were used; EDTA is a general chelating agent, EGTA is a calcium specific chelating agent, and PMSF is a serine protease inhibitor. All previous inhibitors were utilized to find the role of metal ions and serine residue in the enzyme active site, respectively.

In the current study, the tested inhibitors that are synthetic had a significant decline in the lipase activity purified from G. mellonella larvae fat body. The previous results indicated that fat body lipase requires metal ions especially calcium, and had a serine residue at their active site. The PMSF effect was also revealed in TAGlipase activity from the sand fly Phlebotomus papatasi reproductive accessory glands (Rosetto et al., 2003) and Rhynchophorus palmarum (Santana et al., 2017). Also it was proven that the active-site serine residue is portion of a preserved sequence (GXSXG) that has been discovered in most lipase sequences of mammals and 
prokaryotes (Gupta et al. 2004; Hide et al. 1992; Holm et al. 1988) and invertebrate lipases such as insects (Grillo et al. 2007; Horne et al. 2009) and crustacean (Rivera-Pérez and García-Carreño, 2010).

It is important to determine the kinetic parameters of the enzyme as it gives us important information about enzyme behavior and efficiency. The rate of reaction is measured and the influences of changing the reaction conditions are investigated (Walsh et al., 2010). Studying enzyme kinetics from this point of view can provide us with information about the mechanism by which enzyme catalyzes a reaction, metabolic role of enzyme and how enzyme activity can be controlled or inhibited using agonist or drugs (Fromm and Hargrove, 2012). $K_{\mathrm{m}}$ is the substrate concentration at which enzyme reaches to half of its maximal velocity (Schnell and Maini 2004). $K_{\mathrm{m}}$ values of enzymes that activate a specific reaction vary according to the organism from which these enzymes were derived.

In the present study, $K_{\mathrm{m}}$ values for both fat body lipase was high. High $K_{\mathrm{m}}$ values indicate that the enzyme has a low affinity to the substrate. In another word, an enzyme will not be saturated with low concentrations of substrate and needs high concentrations to reach its maximal velocity so enzyme activity depends on substrate concentration (Robinson, 2015). At high substrate concentrations, enzyme reaction rate may reach to its theoretical maximal rate, saturation of enzyme achieved by occupying all of their active sites with substrates and the determination of reaction rate achieved by the intrinsic turnover rate of the enzyme (Wrighton and Ebbing, 1993).

Integrated pest management programs paid attention to the using of enzyme inhibitors. This is because of the wide range use of synthetic pesticides and the appearance of environmental risks such as pest resurgence, pesticide resistance, and poisonous effects on non-target organisms such as human and biocontrol agents. Enzyme inhibitors naturally exist in many food plants and are especially plentiful in cereals like rice and legumes (Zibaee et al. 2008; Zibaee and Bandani, 2010). For example, when the action of digestive enzymes is inhibited, insect's nutrition is impaired, growth, and development are lagging and ultimately death takes place due to starvation. Therefore, a combination of the inhibitors targeting digestive enzymes probably will be more efficient. The enzymatic properties of lipases must be described earlier in considering inhibitors as a control approach.

\section{Conclusion}

A better understanding of Galleria digestive physiology was obtained through purification and characterization of intracellular fat body lipase. With 98.9 fold of purification, this enzyme was found to consist of two monomers of 178.8 and $62.6 \mathrm{kDa} ; \mathrm{Ca}^{2+}$ dependent with a serine residue and its highest activity was shown at 37 and $40{ }^{\circ} \mathrm{C}$ and $\mathrm{pH} 8$. The purified enzyme had a $0.316 \pm$ $1.24 \mathrm{U} / \mathrm{mg}$ protein $V \max$ and $301.59 \pm 24.973 \mathrm{mM} \mathrm{Km}$, and these results will open new research fields such as investigation of hormonal regulation and the effect of various plant extracts on insect enzymes and physiology. That will help in obtaining new strategies for pest management that aim to disrupt pest physiology.

\section{Supplementary information}

Supplementary information accompanies this paper at https://doi.org/10 1186/s41936-019-0134-y.

Additional file 1. Screenshots of the abbreviation of the chemicals; supplementary materials for Figs. 7 and 8.

\section{Acknowledgments}

The authors would like to thank the Dean of the Faculty of Science and the Head of Entomology Department, Ain Shams University for giving

permission to carry out our experiments in the Faculty of Science, Ain Shams University.

\section{Authors' contributions}

RM had performed the practical section of this work, analyzed the data and revised the manuscript. ShM had written and revised the manuscript. MA had written and revised the manuscript. EB had designed the work, analyzed the data, written, and revised the manuscript. All authors had read the manuscript and approved it for submission.

\section{Funding}

Not applicable.

Availability of data and materials

Data for Entomology branch.

Ethics approval and consent to participate

Not applicable.

\section{Consent for publication}

Not applicable.

\section{Competing interests}

The authors declare that they have no competing interest

Received: 2 July 2019 Accepted: 24 October 2019

Published online: 31 December 2019

\section{References}

Agusti, N., \& Cohen, A. C. (2000). Lygus Hesperus and L. lineolaris (Hemiptera: Miridae), phytophagous, zoophagous, or omnivores: evidence of feeding adaptations suggested by the salivary and midgut digestive enzymes. Journal of Entomological Science, 35(2), 176-186.

Arrese, E. L., \& Wells, M. A. (1994). Purification and properties of a phosphorylatable triacylglycerol lipase from the fat body of an insect, Manduca sexta. Journal of Lipid Research, 35(9), 1652-1660.

Auerswald, L., \& Gäde, G. (2006). Endocrine control of TAG lipase in the fat body of the migratory locust, Locusta migratoria. Insect Biochemistry and Molecular Biology, 36(10), 759-768.

Barriga González, A. A. (2006). Enzimas lipolíticas de krill antártico: purificación y caracterización, i enzimas adaptadas al frío?

Bradford, M. M. (1976). A rapid and sensitive method for the quantitation of microgram quantities of protein utilizing the principle of protein-dye binding. Analytical Biochemistry, 72(1-2), 248-254.

Burges, H. D. (1978). Control of wax moths: Physical, chemical and biological methods. Bee World, 59(4), 129-138.

Caron, D. M. (1992). Wax moth. American Bee Journal, 132(10), 647-649. 
Cherif, S., Fendri, A., Miled, N., Trabelsi, H., Mejdoub, H., \& Gargouri, Y. (2007). Crab digestive lipase acting at high temperature: purification and biochemical characterization. Biochimie, 89(8), 1012-1018.

Fromm, H. J., \& Hargrove, M. S. (2012). Enzyme kinetics. In Essentials of biochemistry. Berlin, Heidelberg: Springer.

Fuchs, B. B., O'Brien, E., El Khoury, J. B., \& Mylonakis, E. (2010). Methods for using Galleria mellonella as a model host to study fungal pathogenesis. Virulence, 1(6), 475-482.

Grillo, L. A., Majerowicz, D., \& Gondim, K. C. (2007). Lipid metabolism in Rhodnius prolixus (Hemiptera: Reduviidae): role of a midgut triacylglycerol-lipase. Insect Biochemistry and Molecular Biology, 37(6), 579-588.

Gupta, R., Gupta, N., \& Rathi, P. (2004). Bacterial lipases: an overview of production, purification and biochemical properties. Applied Microbiology and Biotechnology, 64(6), 763-781.

Hide, W. A., Chan, L., \& Li, W. H. (1992). Structure and evolution of the lipase superfamily. Journal of Lipid Research, 33(2), 167-178.

Holm, C., Kirchgessner, T. G., Svenson, K. L., Fredrikson, G., Nilsson, S., Miller, C. G. \& Mohandas, T. (1988). Hormone-sensitive lipase: sequence, expression, and chromosomal localization to 19 cent-q13. 3. Science, 241(4872), 1503-1506.

Horne, I., Haritos, V. S., \& Oakeshott, J. G. (2009). Comparative and functional genomics of lipases in holometabolous insects. Insect Biochemistry and Molecular Biology, 39(8), 547-567.

Hubert, J., Sustr, V., \& Smrz, H. (1999). Feeding of oribatid mite Scheloribates laevigatus (Acari: Oribatida) in the laboratory experiment. Pedobiologia, 43(4), 328-339.

Kim, K. K., Song, H. K., Shin, D. H., Hwang, K. Y., \& Suh, S. W. (1997). The crystal structure of a triacylglycerol lipase from Pseudomonas cepacia reveals a highly open conformation in the absence of a bound inhibitor. Structure, 5(2), 173-185.

Kulkarni, N., Kushwaha, D. K., Mishara, V. K., \& Paunikar, S. (2012). Effect of economical modification in artificial diet of greater wax moth Galleria mellonella (Lepidoptera: Pyralidae). Indian Journal of Entomology, 74(4), 369-374.

Laemmli, U. K. (1970). Cleavage of structural proteins during the assembly of the head of bacteriophage T4. Nature, 227(5259), 680.

Marepally, L., \& Benarjee, G. (2016). Isolation and purification of lipase from the midgut of fifth instar larvae of Antheraea mylitta drury. British Biotechnology Journal, 12(4), 1

Miled, N., Canaan, S., Dupuis, L., Roussel, A., Rivière, M., Carrière, F., \& Verger, R. (2000). Digestive lipases: from three-dimensional structure to physiology. Biochimie, 82(11), 973-986.

Mrdaković, M., Lazarević, J., Perić-Mataruga, V., Ilijin, L., \& Vlahović, M. (2008). Partial characterization of a lipase from gypsy moth (Lymantria dispar L.) larval midgut. Folia Biologica, 56(1-1), 103-110.

Oh, H. W., Lee, M. Y., \& Chang, Y. D. (1995). Developing periods and damage patterns of combs by the greater wax moth, Galleria mellonella. Korean Journal of Apiculture (Korea Republic)., 10(1), 5-10.

Orscelk, O., Akpinar, M. A., \& Gorgun, S. (2007). Partial purification of total body lipase from Gryllus campestris L.(Orthoptera: Gryllidae). Fen Bilimleri Dergisi, 27, 1-10.

Patel, R. T., Soulages, J. L., Hariharasundaram, B., \& Arrese, E. L. (2005). Activation of the lipid droplet controls the rate of lipolysis of triglycerides in the insect fat body. Journal of Biological Chemistry, 280(24), 22624-22631.

Ponnuvel, K. M., Nakazawa, H., Furukawa, S., Asaoka, A., Ishibashi, J., Tanaka, H., \& Yamakawa, M. (2003). A lipase isolated from the silkworm Bombyx mori shows antiviral activity against nucleopolyhedrovirus. Journal of Virology, 77(19), 10725-10729.

Prim, N., Sánchez, M., Ruiz, C., Pastor, F. J., \& Diaz, P. (2003). Use of methylumbeliferyl-derivative substrates for lipase activity characterization. Journal of Molecular Catalysis B: Enzymatic, 22(5-6), 339-346.

Ranjbar, M., Zibaee, A., \& Sendi, J. J. (2015). Purification and characterization of a digestive lipase in the midgut of Ectomyelois ceratoniae Zeller (Lepidoptera: Pyralidae). Frontiers in Life Science, 8(1), 64-70.

Rivera-Pérez, C., \& García-Carreño, F. (2011). Purification and characterization of an intracellular lipase from pleopods of whiteleg shrimp (Litopenaeus vannamei). Comparative Biochemistry and Physiology Part B: Biochemistry and Molecular Biology, 158(1), 99-105.

Rivera-Pérez, C., \& García-Carreño, F. L. (2010). Digestive lipase activity through development and after fasting and re-feeding in the whiteleg shrimp Penaeus vannamei. Aquaculture, 300(1-4), 163-168.

Robinson, P. K. (2015). Enzymes: principles and biotechnological applications. Essays in Biochemistry, 59, 1-41.
Rosetto, M., Belardinelli, M., Fausto, A. M., Marchini, D., Bongiorno, G., Maroli, M., \& Mazzini, M. (2003). A mammalian-like lipase gene is expressed in the female reproductive accessory glands of the sand fly Phlebotomus papatasi (Diptera, Psychodidae). Insect Molecular Biology, 12(5), 501-508.

Roussel, A., Canaan, S., Egloff, M. P., Rivière, M., Dupuis, L., Verger, R., \& Cambillau, C. (1999). Crystal structure of human gastric lipase and model of lysosomal acid lipase, two lipolytic enzymes of medical interest. Journal of Biological Chemistry, 274(24), 16995-17002.

Santana, C. C., Barbosa, L. A., Júnior, I. D. B., Nascimento, T. G. D., Dornelas, C. B., \& Grillo, L. A. (2017). Lipase activity in the larval midgut of Rhynchophorus palmarum: biochemical characterization and the effects of reducing agents. Insects, 8(3), 100.

Schnell, S., \& Maini, P. K. (2004). A century of enzyme kinetics: reliability of the $K_{M}$ and $V_{\max }$ estimates. Comments on Theoretical Biology., 8(2-3), 169-187.

Stauffer, C. E. (1989). Enzyme assays for food scientists, (p. 317). New York: Van Nostrand Reinhold, USA.

Terra, W. R., \& Ferreira, C. (2012). Biochemistry and molecular biology of digestion. Insect molecular biology and biochemistry, 365-418.

Torres, J. B., \& Bayd, D. W. (2009). Zoophytophagy in predatory Hemiptera. Brazilian Archives of Biology and Technology, 52(5), 1199-1208.

Tsujita, T., Ninomiya, H., \& Okuda, H. (1989). p-Nitrophenyl butyrate hydrolyzing activity of hormone-sensitive lipase from bovine adipose tissue. Journal of Lipid Research, 30(7), 997-1004.

Van der Horst, D. J., Van Marrewijk, W. J., \& Diederen, J. H. (2001). Adipokinetic hormones of insect: release, signal transduction, and responses. International Review of Cytology, 211, 179-240.

Walsh, R., Martin, E., \& Darvesh, S. (2010). A method to describe enzyme-catalyzed reactions by combining steady state and time course enzyme kinetic parameters. Biochimica et Biophysica Acta, 1800(1), 1-5.

Wlodawer, P., \& Lagwinska, E. (1967). Uptake and release of lipids by the isolated fat body of the wax moth larva. Journal of Insect Physiology, 13(3), 319-331.

Wolins, N. E., Brasaemle, D. L., \& Bickel, P. E. (2006). A proposed model of fat packaging by exchangeable lipid droplet proteins. FEBS Letters, 580(23), 5484-5491.

Wrighton, M. S., \& Ebbing, D. D. (1993). General chemistry, (4th ed., ). Boston: Houghton Mifflin.

Zeng, F., \& Cohen, A. C. (2000a). Partial characterization of a-amylase in the salivary glands of Lygus hesperus and L. lineolaris. Comparative Biochemistry and Physiology Part B: Biochemistry and Molecular Biology, 126(1), 9-16.

Zeng, F., \& Cohen, A. C. (2000b). Comparison of a-amylase and protease activities of a zoophytophagous and two phytozoophagous heteroptera. Comparative Biochemistery and physiology part A: molecular and integrative physiology, 126(1), 101-106.

Zibaee, A. (2012). A digestive lipase of Pieris brassicae L. (Lepidoptera: Pieridae): purification, characterization, and host plants effects. Archives of Insect Biochemistry and Physiology, 81(1), 1-19.

Zibaee, A., \& Bandani, A. R. (2010). Effects of Artemisia annua L. (Asteracea) on digestive enzymes profiles and cellular immune reactions of sunn pest, Eurygaster integriceps (Heteroptera: Scutellaridae), against Beauvaria bassiana. Bulletin of Entomological Research, 100, 185-196.

Zibaee, A., Bandani, A. R., \& Ramzi, S. (2008). Lipase and invertase activities in midgut and salivary glands of Chilo suppressalis (Walker) (Lepidoptera, Pyralidae), rice striped stem borer. Invertebrate Survival Journal, 5, 180-189.

\section{Publisher's Note}

Springer Nature remains neutral with regard to jurisdictional claims in published maps and institutional affiliations. 